\title{
Determinants of Effects of Foreign Direct Investment in Terms of Slovak Republic and Wood-Processing Industry of Slovakia
}

\section{Odrednice učinkovitosti izravnih stranih ulaganja u uvjetima poslovanja Republike Slovačke i slovačke drvoprerađivačke industrije}

\author{
Review paper • Pregledni rad \\ Received-prispjelo: 12. 7. 2011. \\ Accepted-prihvaćeno: 9. 2. 2012 \\ UDK: $630 * 79$ \\ doi:10.5552/drind.2012.1136
}

\begin{abstract}
The presence of foreign direct investment in certain sectors or country determines several factors the determinants of foreign direct investment. The article analyzes the selected factors of FDI inflows to the Slovak Republic and to the wood-processing industry in SR; it focuses primarily on assessing the contemporary situation of the business environment in Slovakia and investment incentives provided to foreign investors. The article also presents the development of foreign direct investment in Slovakia, in the branch of wood processing, analyzing the effects of FDI in specific conditions of the Slovak Republic and wood-processing industry.
\end{abstract}

Key words: foreign direct investment (FDI), effects of FDI, business environment, investment incentives, woodprocessing branch

SAŽETAK • Zastupljenost izravnih stranih ulaganja (FDI) u pojedinim sektorima ili državi određen je s nekoliko čimbenika - čimbenika izravnih stranih ulaganja. U članku se analiziraju određeni čimbenici FDI-a u Slovačkoj Republici i u drvoprerađivačkoj industriji Slovačke, pri čemu se autori primarno fokusiraju na pristup trenutačnoj situaciji u poslovnom okruženju u Slovačkoj i na ulagačke poticaje koje strani ulagači imaju. Članak također predočuje razvoj izravnih stranih ulaganja u Slovačku, u drvoprerađivačku djelatnost, analizirajući učinke FDI-a u specifičnim uvjetima u kojima se prerada drva u Slovačkoj nalazi.

Ključne riječi: izravna strana ulaganja (FDI), učinci FDI, poslovno okruženje, ulagački poticaji, drvoprerađivačka djelatnost

\footnotetext{
${ }^{1}$ Authors are assistant and associated professor at Faculty of Wood Sciences and Technology, Technical University in Zvolen, Zvolen, Slovak Republic. ${ }^{2}$ Author is professor at Faculty of Forestry, University of Zagreb, Zagreb, Croatia.

Autori su asistentica i izvanredni profesor Fakulteta znanosti o drvu i drvne tehnologije Tehničkog sveučilišta u Zvolenu, Zvolen, Republika Slovačka. ${ }^{2}$ Autor je profesor Šumarskog fakulteta Sveučilišta u Zagrebu, Zagreb, Hrvatska.
} 


\section{INTRODUCTION}

\section{UVOD}

The inflow of foreign direct investments (FDI) into the country affects a number of factors described in literature or published annually for example in UNCTAD surveys. Major factors in terms of savings are low labor costs, availability of resources (material, energy, financial). On the other hand, factors that influence revenues are usually market size and market growth (World Investment Prospect Survey, 2009). However, it is also important to evaluate factors that affect the business environment and the presence of foreign investors in the country. These factors are condition and quality of business environment, the level of corruption, but also the rate of assistance from the state investment incentives (Ferenčíková et al, 2010).

The results of analysis of rating institutions show that the attractiveness of some country for foreign direct investment is crucially dependent on favorable business environment, the quality of institutional environment, as well as the relative price and cost competitiveness (Drábek and Polách, 2008). However, the dynamics of FDI flow is significantly influenced by the targeted state policy to promote foreign investments (Drábek and Jelačić, 2007). Results of the global economic crisis, as well as the acceptance of a comprehensive system of measures to reduce them, may affect not only the long-term macroeconomic stability, but also the policy towards FDI, and hence foreign direct investment inflows to Slovakia both in the short and long term.

It can be concluded that maintaining long-term political stability in Slovakia is also reflected positively on the real economy, which is impacted in the continuity of macroeconomic stability and keeping up the suitable business environment. The evaluation of the International Monetary Fund $(I M F, 2009)$ shows that long term positive economic development in the SR is manifested in the rapid GDP growth, which was based on health macroeconomic and structural policies and helped to speed up the convergence process of the Slovak economy. Since the Slovak economy is an open and export-oriented economy, its development is significantly influenced by development in the external economic environment. This is confirmed by time-coordinated course of the economic crisis in the external environment and in Slovakia, which also shows that the Slovak economy is tightly integrated into European and world economy (Okáli et al, 2009). Simultaneously, the imported recession also causes many negative consequences on the domestic economy. Such close connection with the external environment is also reflected in forecasts of economic development for the years 2012-2015, which can be evaluated as positive in comparison with other EU countries.

The government deficit exceeding $3 \%$ of GDP is not the cause for investors concerns in the current situation. However, the expected economic recovery will be reflected in the re-tightening of the fiscal policy, and it will be a positive signal to encourage the investor confidence, underlining the government's responsible approach to meeting the commitments under the Stability and Growth Pact (SGP).
The main objective of each company is an efficient and successful business. There is a general economic principle: to achieve the maximum result with the minimum of means (Oblak et al, 2008, Stasiak-Betlejewska et al, 2007). The objective of this research was to evaluate the impact of investment and foreign direct investment in the Slovak Republic with the focus on the woodprocessing industry in SR all based on the analysis of time series of selected economic indicators, business and investment environment and investment incentives.

To achieve this objective partial objectives were formulated:

- the analysis of foreign direct investment in the Slovak Republic as well as in individual sectors of the wood-processing industry, analysis of the business and investment environment, investment incentives in Slovakia,

- the evaluation of selected economic indicators in SR and wood-processing industry of SR with the application of selected statistical methods (correlation and regression analysis), the interpretation of the solution and obtained results.

\section{METHODOLOGY OF RESEARCH 2. METODA ISTRAŽIVANJA}

Statistical methods were used to analyze and evaluate the effects of investment in SR and in wood-processing industry of SR. Correlation analysis describes the relationship between two quantitative variables. This analysis does not imply cause and effect relationship between two variables. Linear regression allows to examine the cause and the subsequent relationship between two variables $x$ and $y$. The regression line determines the dependence. The chart of correlation and linear regression analysis shows the values of independent and dependent variables in each year and the regression line. Values closer to the regression line mean stronger impact on the examined variable.

Correlation and regression analysis of research focuses on foreign direct investment in Slovakia, the GDP growth of Slovakia, investment and selected variables in the wood-processing branch. These are indicators that characterize the economic situation in the mentioned sector, focusing on indicators that have a positive impact on the economic development of the wood-processing industry.

The selected economic indicators are evaluated over a period of 10 years in the 1999-2008 time series. Software products STATISTICA 9 of the company StatSoft and the application Excel from Microsoft Office 2003 from Microsoft, as well as spreadsheet and graphics tools of applications were used for data processing.

\section{RESULTS AND DISCUSSION} 3. REZULTATI I RASPRAVA

\subsection{Business environment in Slovakia} 3.1. Poslovno okruženje u Slovačkoj

Generally, it can be stated that the business environment in Slovakia is not quite good. According to the 
Table 1 Index of Economic Freedom worldwide in 2010

Tablica 1. Indeks ekonomske slobode u svijetu u 2010. godini

\begin{tabular}{|c|c|l|c|c|c|c|c|c|c|c|c|c|}
\hline $\begin{array}{c}\text { World } \\
\text { Rank } \\
\begin{array}{c}\text { Mjesto } u \\
\text { svijetu }\end{array}\end{array}$ & $\begin{array}{c}\text { Overall } \\
\text { Index } \\
\text { Ukupni } \\
\text { indeks }\end{array}$ & Country & {$[1]$} & {$[2]$} & {$[3]$} & {$[4]$} & {$[5]$} & {$[6]$} & {$[7]$} & {$[8]$} & {$[9]$} & {$[10]$} \\
\hline 1. & 89,7 & Hong Kong & 98.7 & 90.0 & 93.0 & 93.7 & 83.1 & 90.0 & 90.0 & 90.0 & 81.0 & 87.4 \\
\hline 2. & 86,1 & Singapore & 98.2 & 90.0 & 90.7 & 95.3 & 80.9 & 75.0 & 50.0 & 90.0 & 92.0 & 98.9 \\
\hline 3. & 82,6 & Australia & 90.3 & 85.1 & 61.4 & 64.9 & 82.7 & 80.0 & 90.0 & 90.0 & 87.0 & 94.0 \\
\hline 4. & 82,1 & New Zealand & 99.9 & 86.0 & 63.6 & 51.3 & 83.1 & 80.0 & 80.0 & 95.0 & 93.0 & 88.8 \\
\hline 5. & 81,3 & Ireland & 92.8 & 87.5 & 71.1 & 61.8 & 79.0 & 95.0 & 80.0 & 90.0 & 77.0 & 79.0 \\
\hline 6. & 81,1 & Switzerland & 81.2 & 90.0 & 68.2 & 68.9 & 81.3 & 80.0 & 80.0 & 90.0 & 90.0 & 81.8 \\
\hline 7. & 80,4 & Canada & 96.5 & 88.1 & 76.7 & 54.1 & 75.4 & 75.0 & 80.0 & 90.0 & 87.0 & 81.5 \\
\hline 8. & 78,0 & United States & 91.3 & 86.9 & 67.5 & 58.0 & 78.0 & 75.0 & 70.0 & 85.0 & 73.0 & 94.8 \\
\hline 9. & 77,9 & Denmark & 97.9 & 87.5 & 35.9 & 22.0 & 79.3 & 90.0 & 90.0 & 90.0 & 96.0 & 93.7 \\
\hline 10. & 77,2 & Chile & 64.8 & 88.0 & 77.5 & 89.6 & 73.0 & 80.0 & 70.0 & 85.0 & 69.0 & 75.4 \\
\hline 34. & 69,8 & Czech Republic & 65.5 & 87.5 & 80.1 & 45.6 & 75.6 & 70.0 & 80.0 & 65.0 & 52.0 & 76.4 \\
\hline 35. & 69,7 & Slovak Republic & 72.6 & 87.5 & 84.0 & 64.5 & 78.2 & 70.0 & 70.0 & 55.0 & 50.0 & 65.0 \\
\hline 51. & 66,1 & Hungary & 76.8 & 87.5 & 68.6 & 25.9 & 74.1 & 75.0 & 70.0 & 65.0 & 51.0 & 67.6 \\
\hline 71. & 63,2 & Poland & 62.2 & 87.5 & 74.9 & 46.8 & 78.1 & 60.0 & 60.0 & 55.0 & 46.0 & 61.5 \\
\hline 177. & 26,7 & Cuba & & & & & & & & & & \\
\hline 178. & 21,4 & Zimbabwe & & & & & & & & & & \\
\hline 179. & 1,0 & North Korea & & & & & & & & & & \\
\hline
\end{tabular}

Scale 0-100, 100 - maximum freedom, Source: data from heritage.org/Index

Skala 0-100, 100 - maksimalna sloboda; Izvor: podaci s heritage.org/Index

Slovak Chamber of Commerce and Industry (SCCI), it is getting gradually worse. The survey of SCCI shows that $71 \%$ of the 170 surveyed companies consider the business environment as adverse. Only $2 \%$ of surveyed companies identified the Slovak business environment as favorable. Based on the survey, it follows that $59 \%$ of surveyed companies expect no change in the business environment. Only $6 \%$ of respondents expect improving of the business environment and $35 \%$ its further deterioration.

Slovakia had its economic growth based on the quality of business environment, of course using the comparative advantages which the country still has, but their strength in relation to other countries gradually weakens (Merková and Drábek, 2010). Justice and legislation are among the worst areas of business environment in Slovakia. Worse legislative environment according to the SCCI survey is particularly evident in the rapid adoption of amendments and laws (Merková, 2010).

The situation of the business environment in Slovakia and other countries was analyzed on the basis of five ratings - indexes and rankings compiled by various world expert organizations and institutions. Ratings are not only supported by statistical data of the economic development of countries; they are the result of experts' opinions and independent assessors' perceptions of the development of each country in comparison with the development in other economies. Although rankings are not scientific facts, the mentioned institutions that compiled the rankings are considered as independent, objective and credible. The ratings reflect the perceptions of the situation in the country from the perspective of the business sector.

\subsection{Index of Economic Freedom} 3.1.1. Indeks ekonomske slobode

According to the Index of Economic Freedom ${ }^{l}$ in 2010, Slovakia improved by 0.3 points and was ranked $35^{\text {th }}$ with the overall assessment of 69.7 points (in 2009 it was 69.4 points, $36^{\text {th }}$ place). The overall score is higher than the world average. The Czech Republic took the highest position among V4 countries after five years, and was ranked $34^{\text {th }}\left(37^{\text {th }}\right.$ in 2009$)$. Hungary was ranked $51^{\text {st }}\left(44^{\text {th }}\right.$ in 2009$)$ and Poland $71^{\text {st }}\left(82^{\text {nd }}\right.$ step in 2009). However, Poland is included among top ten countries with the best annual improvement in the ranking. According to the European region, Slovakia ranked $18^{\text {th }}$ out of 43 countries (in 2009 it was ranked $20^{\text {th }}$ ). The former British colony of Hong Kong has been declared the freest economy in the world for 16 times.

The Index of Economic Freedom contains ten subcriteria:

[1] Business Freedom [6] Investment Freedom

[2] Trade Freedom [7] Financial Freedom

[3] Fiscal Freedom [8] Property Rights

[4] Government [9] Freedom from Spending Corruption

[5] Monetary Freedom [10] Labor Freedom

Experts in evaluation of Slovakia show a significant deterioration in the category of freedom in the labor market, but offset by improvements in other areas. Slovakia is still limited by two institutional weaknesses - the judicial system is inefficient and slow, and in recent years efforts to eliminate the corruption have

\footnotetext{
Economic Freedom Score is compiled and published by the Heritage Foundation, Washington No.1 think tank and the Wall Street Journal, the index covers 183 countries.
} 
Table 2 Index of Economic Freedom in V4 countries in the period 2008-2010

Tablica 2. Indeks ekonomske slobode za zemlje Višegradske skupine V4 u razdoblju 2008 -2010.

\begin{tabular}{|l|c|c|c|}
\hline $\begin{array}{l}\text { Country } \\
\text { Država }\end{array}$ & Rank in 2010 & Rank in 2009 & $\begin{array}{c}\text { Rank in 2008 } \\
\text { Mjesto u svijetu } \text { u 2010. }\end{array}$ \\
\hline Czvijetu u 2008.
\end{tabular}

Source: data from heritage.org/Index / Izvor: podaci s heritage.org/Index

shown only limited progress; in the long-term perspective, investors consider these weaknesses to be a serious factor in locating the foreign enterprises.

\subsubsection{Ease of Doing Business}

\subsubsection{Lakoća poslovanja}

In the Ease of Doing Business ${ }^{2}$ Slovakia was ranked worse in 2010 than in previous years. Among all countries, Slovakia fell from $32^{\text {nd }}$ place in 2008 to $35^{\text {th }}$ in 2009 and $42^{\text {nd }}$ in 2010. Although Slovakia has maintained its leading position among the V4 countries (Czech Republic is $74^{\text {th }}$, Hungary $47^{\text {th }}$ and Poland $72^{\text {nd }}$ ), Slovakia is lagging behind faster reformers of Eastern Europe such as Georgia, Estonia, Latvia and Lithuania. Despite this, however, Slovakia overtook five industrially more developed economies of Europe (Portugal $48^{\text {th }}$, Spain $62^{\text {nd }}$, Luxembourg $64^{\text {th }}$, Italy $78^{\text {th }}$, Greece $\left.109^{\text {th }}\right)$. Unexpectedly, Slovakia as the largest manufacturer of automobiles per capita in the world, belongs to the countries in the EU with the lowest "trading across borders". The Slovak government needs to reduce requirements and shorten the time required for exports and imports, and to optimize this process through competitiveness and transparency.

Slovakia can support the entrepreneurial spirit by simplifying the procedures for starting business and by providing steps aimed at simplifying business registration and making it more acceptable for enterprises. In

2 Ease of Doing Business - data compiled by the World Bank and International Finance Corporation in the report Doing Business, giving analysis of 183 countries. Annual report 2010 covers data in the period June 2008 to May 2009.

Source of data: http://www.doingbusiness.org addition, the report of Doing Business indicates that Slovakia needs to shorten the time needed for the enforcement of contracts and decrease costs associated with enforcement. Slovakia has one of the longest waiting times among European countries for obtaining a building permit (287 days), followed only by Poland (308 days) and Cyprus (677 days). This is especially troubling when compared with countries such as Finland or Denmark, where the same may be carried out in 38 or 69 days according to the World Bank.

Slovakia has a poor rating in the category of closing the business, particularly in two areas: the duration of the bankruptcy settlement - about 4 years (followed only by the Czech Republic with a period of 6.5 years) and bankruptcy costs as a percentage of assets, which is $18 \%$ in Slovakia as well as in Austria (followed by Poland with only $20 \%$ and Italy with $22 \%$ ). Slovakia has a better score than most EU countries in the cost of obtaining a building permit (the second lowest in the EU, 13.8 multiple of the average wage). Building permits in Hungary is 9.8 times higher than the average wage, while in Bulgaria it is an overwhelming factor - 436.5 times more than the average wage. Investors may obtain a building permit in Slovakia completing 13 treatments, which is less than most other EU countries require (Report on the state of business environment in SR, Ministry of Economy, 2010).

What makes Slovakia particularly attractive is the process of acquiring ownership. Slovakia is the country with the lowest costs for this process, which is very fast and efficient. Slovakia is among the top six countries in the strength of their legal rights in obtaining the loan. This index measures the protection rules in relation to

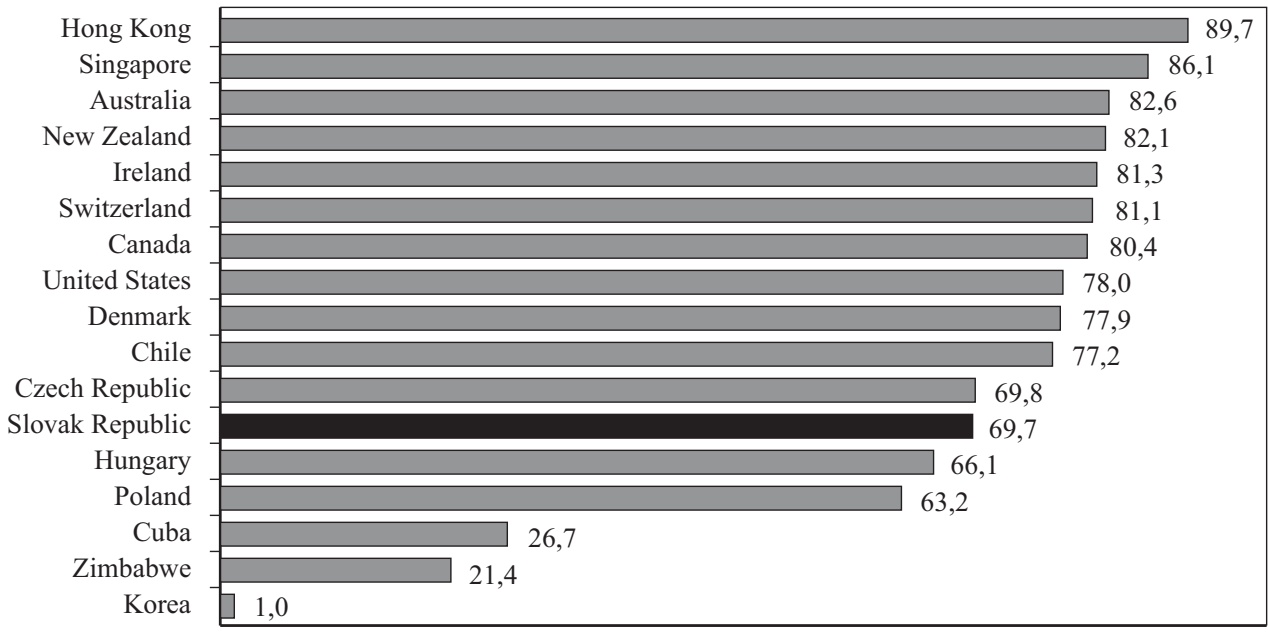

Figure 1 Index of Economic Freedom in 2010 (Source: data from heritage.org/Index)

Slika 1. Indeks ekonomske slobode u 2010. godini (izvor: podaci s heritage.org/Index) 
Table 3 Ease of Doing Business worldwide in 2010

Tablica 3. Lakoća poslovanja u svijetu za 2010. godinu

\begin{tabular}{|c|l|c|c|c|c|c|c|c|c|c|c|}
\hline $\begin{array}{c}\text { World Rank } \\
\text { Mjesto u svijetu }\end{array}$ & $\begin{array}{l}\text { Country } \\
\text { Država }\end{array}$ & {$[1]$} & {$[2]$} & {$[3]$} & {$[4]$} & {$[5]$} & {$[6]$} & {$[7]$} & {$[8]$} & {$[9]$} & {$[10]$} \\
\hline 1. & Singapore & 4 & 2 & 1 & 16 & 4 & 2 & 5 & 1 & 13 & 2 \\
\hline 2. & New Zealand & 1 & 5 & 15 & 3 & 4 & 1 & 9 & 26 & 10 & 17 \\
\hline 3. & Hong Kong, China & 18 & 1 & 6 & 75 & 4 & 3 & 3 & 2 & 3 & 13 \\
\hline 4. & United States & 8 & 25 & 1 & 12 & 4 & 5 & 61 & 18 & 8 & 15 \\
\hline 5. & United Kingdom & 16 & 16 & 35 & 23 & 2 & 10 & 16 & 16 & 23 & 9 \\
\hline 6. & Denmark & 28 & 10 & 9 & 47 & 15 & 27 & 13 & 6 & 28 & 7 \\
\hline 7. & Ireland & 9 & 30 & 27 & 79 & 15 & 5 & 6 & 21 & 37 & 6 \\
\hline 8. & Canada & 2 & 29 & 17 & 35 & 30 & 5 & 28 & 38 & 58 & 4 \\
\hline 9. & Australia & 3 & 62 & 1 & 34 & 4 & 57 & 47 & 27 & 16 & 14 \\
\hline 10. & Norway & 35 & 65 & 114 & 8 & 43 & 20 & 17 & 9 & 4 & 3 \\
\hline 42. & Slovak Republic & 66 & 56 & 81 & 11 & 15 & 109 & 119 & 113 & 61 & 39 \\
\hline 47. & Hungary & 39 & 87 & 77 & 61 & 30 & 119 & 122 & 70 & 14 & 58 \\
\hline 72. & Poland & 117 & 163 & 76 & 88 & 15 & 41 & 151 & 42 & 75 & 85 \\
\hline 74. & Czech Republic & 113 & 76 & 25 & 62 & 43 & 93 & 121 & 53 & 82 & 116 \\
\hline 181. & Guinea-Bissau & & & & & & & & & & \\
\hline 182. & Congo, Dem. Rep. & & & & & & & & & & \\
\hline 183. & Central African Republic & & & & & & & & & \\
\hline
\end{tabular}

Source: data of Doing Business / Izvor: podaci s Doing Businessa

Table 4 Ranking of V4 countries in global ranking of Doing Business in the period 2006-2010

Tablica 4. Mjesto zemalja V4 u globalnom redoslijedu Doing businessa za razdoblje 2006 - 2010.

\begin{tabular}{|l|c|c|c|c|c|}
\hline $\begin{array}{l}\text { Country } \\
\text { Država }\end{array}$ & $\begin{array}{c}\text { Report 2010 } \\
\text { Izvješće za 2010. }\end{array}$ & $\begin{array}{c}\text { Report 2009 } \\
\text { Izvješće za 2009. }\end{array}$ & $\begin{array}{c}\text { Report 2008 } \\
\text { Izvješće za 2008. }\end{array}$ & $\begin{array}{c}\text { Report 2007 } \\
\text { Izvješće za 2007. }\end{array}$ & $\begin{array}{c}\text { Report 2006 } \\
\text { Izvješće za 2006. }\end{array}$ \\
\hline Slovak Republic & 42. & 35. & 32. & 36. & 34. \\
\hline Czech Republic & 74. & 66. & 56. & 52. & 50. \\
\hline Hungary & 47. & 41. & 45. & 66. & 60. \\
\hline Poland & 72. & 72. & 74. & 75. & 74. \\
\hline
\end{tabular}

Source: data from Doing Business / Izvor: podaci s Doing Businessa

the possession of movable property. However, Slovakia was ranked between $18^{\text {th }}$ and $23^{\text {rd }}$ place in terms of quality and availability of debt information obtained from public and private debt registries (rokovania.sk). In EU Slovakia is ranked between the $7^{\text {th }}$ and $10^{\text {th }}$ place according to the employment index, which evaluates the rules for hiring people, working time, number of leave days and statutory requirements for dismissal of employees for economic reasons (spectator.sk).

The Ease of Doing Business consists of ten indicators:

[1] Starting a Business [6] Protecting Investors

[2] Dealing with

Construction Permits [7] Paying Taxes

[3] Employing Workers [8] Trading Across Borders

[4] Registering Property [9] Enforcing Contracts

[5] Getting Credit [10]Closing a Business

\subsubsection{Global Competitiveness Index}

3.1.3. Indeks globalne kompetitivnosti

According to the Global Competitiveness Index ${ }^{3}$ Slovakia was ranked in the group of developed countri-

\footnotetext{
3 Global Competitiveness Index compiled by the World Economic Forum annually in the Global Competitiveness Report, covers 133 countries. Source of data: http://www.weforum.org/documents/ GCR09/index.html
}

es in 2009 for the first time (based on last year's GDP level); the economic development of these countries is mainly based on the ability to innovate.

The Index consists of 12 pillars of competitiveness:
[1] Institutions
[7] Labor market efficiency
[2] Infrastructure
[8] Financial market development

[3] Macroeconomic environment

[9] Technological readiness

[4] Health and primary education

[10] Market size

[5] Higher education and training

[6] Goods market efficiency

[11] Business sophistication

Slovakia was gradually decreasing from the $36^{\text {th }}$ place in 2006 to $37^{\text {th }}, 41^{\text {st }}, 46^{\text {th }}$ and finally $47^{\text {th }}$ place in 2010. The Czech Republic annually rose by 2 positions, Poland's position improved by 7 places and Hungary also moved upward. Slovakia is, thus, the only country from the V4 group, rating decreases.

According to the Executive Director of the Business Alliance of Slovakia, which is a partner institution of the World Economic Forum, the global economic crisis means that most countries assessed lower competitiveness index score this year. However, due to the strong 
Table 5 Global Competitiveness Index worldwide in 2010

Tablica 5. Indeks globalne kompetitivnosti u svijetu za 2010. godinu

\begin{tabular}{|c|l|c|c|c|c|c|c|c|c|c|c|c|c|}
\hline $\begin{array}{c}\text { Rank } \\
\text { Mjesto u svijetu }\end{array}$ & Country / Država & {$[1]$} & {$[2]$} & {$[3]$} & {$[4]$} & {$[5]$} & {$[6]$} & {$[7]$} & {$[8]$} & {$[9]$} & {$[10]$} & {$[11]$} & {$[12]$} \\
\hline 1. & Switzerland & 8 & 5 & 17 & 21 & 6 & 5 & 2 & 14 & 3 & 36 & 3 & 2 \\
\hline 2. & United States & 34 & 8 & 93 & 36 & 7 & 12 & 3 & 20 & 13 & 1 & 5 & 1 \\
\hline 3. & Singapore & 1 & 4 & 35 & 13 & 5 & 1 & 1 & 2 & 6 & 39 & 14 & 8 \\
\hline 4. & Sweden & 2 & 14 & 15 & 12 & 3 & 4 & 19 & 12 & 1 & 32 & 4 & 5 \\
\hline 5. & Denmark & 3 & 12 & 14 & 6 & 2 & 7 & 5 & 8 & 4 & 49 & 8 & 10 \\
\hline 6. & Finland & 4 & 10 & 12 & 1 & 1 & 19 & 23 & 7 & 10 & 53 & 9 & 3 \\
\hline 7. & Germany & 16 & 1 & 30 & 24 & 22 & 18 & 70 & 36 & 12 & 5 & 2 & 7 \\
\hline 8. & Japan & 28 & 13 & 97 & 19 & 23 & 17 & 12 & 40 & 255 & 3 & 1 & 4 \\
\hline 9. & Canada & 17 & 7 & 31 & 7 & 9 & 16 & 7 & 11 & 11 & 14 & 17 & 12 \\
\hline 10. & Netherlands & 10 & 15 & 38 & 14 & 10 & 6 & 27 & 23 & 2 & 18 & 6 & 13 \\
\hline 31. & Czech Republic & 62 & 48 & 43 & 33 & 24 & 27 & 20 & 42 & 30 & 40 & 25 & 25 \\
\hline 46. & Poland & 66 & 103 & 74 & 35 & 27 & 53 & 50 & 44 & 48 & 20 & 44 & 52 \\
\hline 47. & Slovak Republic & 78 & 63 & 40 & 48 & 47 & 32 & 29 & 28 & 33 & 57 & 51 & 68 \\
\hline 58. & Hungary & 76 & 57 & 83 & 53 & 35 & 64 & 63 & 69 & 40 & 45 & 76 & 45 \\
\hline 131. & Chad & & & & & & & & & & & & \\
\hline 132. & Zimbabwe & & & & & & & & & & & & \\
\hline 133. & Burundi & & & & & & & & & & & \\
\hline
\end{tabular}

Source: data of Global Competitiveness Report / Izvor: podaci s Global Competitiveness Reporta

Table 6 Global Competitiveness Index in V4 countries in the period 2006-2010

Tablica 6. Indeks globalne kompetitivnosti za zemlje V4 za razdoblje 2006 - 2010.

\begin{tabular}{|l|c|c|c|c|c|}
\hline Country / Država & $2009-2010$ & $2008-2009$ & $2007-2008$ & $2006-2007$ & $2005-2006$ \\
\hline Czech Republic & 31. & 33. & 33. & 29. & 29. \\
\hline Poland & 46. & 53. & 51. & 48. & 43. \\
\hline Slovak Republic & 47. & 46. & 41. & 37. & 36. \\
\hline Hungary & 58. & 62. & 47. & 41. & 35. \\
\hline
\end{tabular}

Source: data of Global Competitiveness Report / Izvor: podaci s Global Competitiveness Reporta

interdependence of economies, there was no pronounced movement in the ranking. Regarding the ranking of Slovakia he says: "Poor government's ability to improve the business environment, reform and eliminate the major barriers of business were the cause for Slovakia to fall in the ranking for the third time in a raw." (alianciapas.sk). The basic disadvantage of Slovakia is that most foreign companies have their innovative potential organized in the home country, so the share of $R \& D$ capacities is gradually reduced, and thus it fails to engage the capacities into innovative projects.

\subsubsection{Global Competitiveness Breakdown} 3.1.4. Smanjenje globalne kompetitivnosti

According to Global Competitiveness Brea$k d o w n^{4}$ Slovakia results in 33rd position in year 2010, occupies second position among V4 countries in longterm situation. The Global Competitiveness Breakdown is compiled on the base of four indicators as economic performance, government efficiency, business efficiency and infrastructure. Each one consists from next five subcriteria.

\footnotetext{
4 Global Competitiveness Breakdown compiled by the Swiss Institute of the International Institute for Management Development in the annual report the World Competitiveness Yearbook, covers 57 countries worldwide. Source of data: http://www.worldcompetitiveness.com
}

\subsubsection{Corruption Perceptions Index}

3.1.5. Indeks percepcije koruptivnosti

In 2009 Slovakia became one of the 9 countries with the worst decline in scores. According to the Corruption Perceptions Index, Slovakia set back four years ago. According to the Corruption Perceptions Index 5 in 2009, the score of Slovakia dropped the most in the history of measurements since 1998, from the level of 5.0 to 4.5 . Slovakia also worsened annually in the countries ranking: it dropped from the $52^{\text {nd }}-53^{\text {rd }}$ to the $56^{\text {th }}-60^{\text {th }}$ place. For the first time since 2001 Slovakia is ranked worst of the V4 countries (Transparency International).

Finally, in connection with the presented ratings, it should be noted that the evaluation does not always reflect the real and actual situation of the country's economy. Can the Index of Economic Freedom be considered as objective, if in 2010 Ireland was ranked 5th, and in

\footnotetext{
5 Corruption Perceptions Index is compiled by the Transparency International, covers 180 countries worldwide. A composite index, the CPI is based on 13 different expert and business surveys. Eight surveys are made for Slovakia every year. Transparency International makes neither of them, and they are made by different institutions. For Slovakia, the last time they were as follows: the World Economic Forum, Freedom House, The Economist Intelligence Unit, International Institute for Management Development, IHS Global Insight and Bertelsmann Foundation.Source of data: http:// www.transparency.sk/vystupy/rebricky/
} 
........ Merková, Drábek, Jelačić: Determinants of Effects of Foreign Direct Investment...

Table 7 Global Competitiveness Breakdown worldwide in 2010

Tablica 7. Smanjenje globalne kompetitivnosti u svijetu za 2010. godinu

\begin{tabular}{|c|l|c|c|c|c|}
\hline $\begin{array}{c}\text { Rank } \\
\text { Mjesto }\end{array}$ & $\begin{array}{l}\text { Country } \\
\text { Država }\end{array}$ & $\begin{array}{c}\text { Economic } \\
\text { Performance } \\
\text { Ekonomski rezultati }\end{array}$ & $\begin{array}{c}\text { Government } \\
\text { Efficiency } \\
\text { Učinkovitost vlade }\end{array}$ & $\begin{array}{c}\text { Business Efficiency } \\
\text { Učinkovitost poslovanja }\end{array}$ & $\begin{array}{c}\text { Infrastructure } \\
\text { Infrastruktura }\end{array}$ \\
\hline 1. & United Nations & 1 & 20 & 16 & 1 \\
\hline 2. & Hong Kong & 3 & 2 & 1 & 19 \\
\hline 3. & Singapore & 8 & 1 & 3 & 8 \\
\hline 4. & Switzerland & 13 & 3 & 2 & 6 \\
\hline 5. & Denmark & 23 & 4 & 6 & 2 \\
\hline 6. & Sweden & 20 & 10 & 7 & 12 \\
\hline 7. & Australia & 15 & 8 & 5 & 7 \\
\hline 8. & Canada & 16 & 9 & 8 & 11 \\
\hline 9. & Finland & 40 & 6 & 36 & 25 \\
\hline 10. & Netherland & 7 & 31 & 26 & 37 \\
\hline 29. & Czech Republic & 25 & 34 & 50 & 39 \\
\hline 33. & Slovak Republic & 34 & 44 & 52 & 33 \\
\hline 44. & Poland & 39 & 50 & & \\
\hline 45. & Hungary & 33 & & & \\
\hline 57. & Venezuela & & & & \\
\hline
\end{tabular}

Source: data of the World Competitiveness Yearbook / Izvor: podaci iz World Competitiveness Yearbooka

Table 8 Global Competitiveness Breakdown in V4 countries in the period 2006-2010

Tablica 8. Smanjenje globalne kompetitivnosti za zemlje V4 u razdoblju 2006 - 2010.

\begin{tabular}{|l|l|l|l|l|l|}
\hline Country / Država & $2009-2010$ & $2008-2009$ & $2007-2008$ & $2006-2007$ & $2005-2006$ \\
\hline Czech Republic & 29. & 28. & 32. & 28. & 30. \\
\hline Slovak Republic & 33. & 30. & 34. & 33. & 34. \\
\hline Poland & 44. & 44. & 52. & 50. & 48. \\
\hline Hungary & 45. & 38. & 35. & 35. & 31. \\
\hline
\end{tabular}

Source: data of the World Competitiveness Yearbook / Izvor: podaci iz World Competitiveness Yearbooka

Table 9 Corruption Perceptions Index worldwide in 2009

Tablica 9. Indeks percepcije koruptivnosti u svijetu za 2009

\begin{tabular}{|c|l|c|}
\hline $\begin{array}{c}\text { Rank } \\
\text { Mjesto }\end{array}$ & $\begin{array}{l}\text { Country } \\
\text { Država }\end{array}$ & $\begin{array}{c}\text { Corruption Perceptions } \\
\text { Index 2009 } \\
\text { Indeks percepcije koruptiv- } \\
\text { nosti za 2009. }\end{array}$ \\
\hline 1. & New Zealand & 9.4 \\
\hline 2. & Denmark & 9.3 \\
\hline 3. & Singapore & 9.2 \\
\hline 3. & Sweden & 9.2 \\
\hline 5. & Switzerland & 9.0 \\
\hline $6 .-7$. & Finland & 8.9 \\
\hline $6 .-7$. & Nederland & 8.9 \\
\hline $8 .-10$. & Australia & 8.7 \\
\hline $8 .-10$. & Canada & 8.7 \\
\hline $8 .-10$. & Iceland & 8.7 \\
\hline 46. & Hungary & 5.1 \\
\hline 49. & Poland & 5.0 \\
\hline 52. & Czech Republic & 4.9 \\
\hline 56. & Slovak Republic & 4.5 \\
\hline 178. & Myanmar & 1.4 \\
\hline 179. & Afghanistan & 1.3 \\
\hline 180. & Somalia & 1.1 \\
\hline
\end{tabular}

Scale: $0-10,10$ being the best, Source: Transparency International data

Skala: 0-10; 10 je najbolj;, izvor: podaci Transparency Internationala
2009 it nearly declared the state bankruptcy due to extreme indebtedness? Can this country be considered economically free in these conditions? The same applies to the USA ( $8^{\text {th }}$ place). Can its Quality of Business Environment be assessed as reliable, if the best ranked countries are those most indebted in the world such as the USA ( $4^{\text {th }}$ place), Great Britain $\left(5^{\text {th }}\right.$ place $)$ and the abovementioned Ireland $\left(7^{\text {th }}\right.$ place $)$ ? Even less credible are the results of the Global Competitiveness Index. According to this indicator the USA are excellent ( $2^{\text {nd }}$ place), and the objectively the most competitive China is ranked $29^{\text {th }}$ place. However, experts' rankings are accepted by investors, of course in terms of their insights into this issue (Drábek and Merková, 2010).

\subsection{Investment incentives for the development of investing}

3.2. Ulagački poticaji za razvoj investiranja

The analyzed data show that Slovakia still has significant comparative advantages (high correlation between wage and labor productivity, low cost of release, index of rights of creditors and debtors, a healthy banking sector, relatively good availability of financing by loans, low duty barriers, support of the FDI, good conditions for technology transfer and FDI), which should be used, while the negative factors that foreign investors analyze with the location of their business activities should be removed (Merková and 


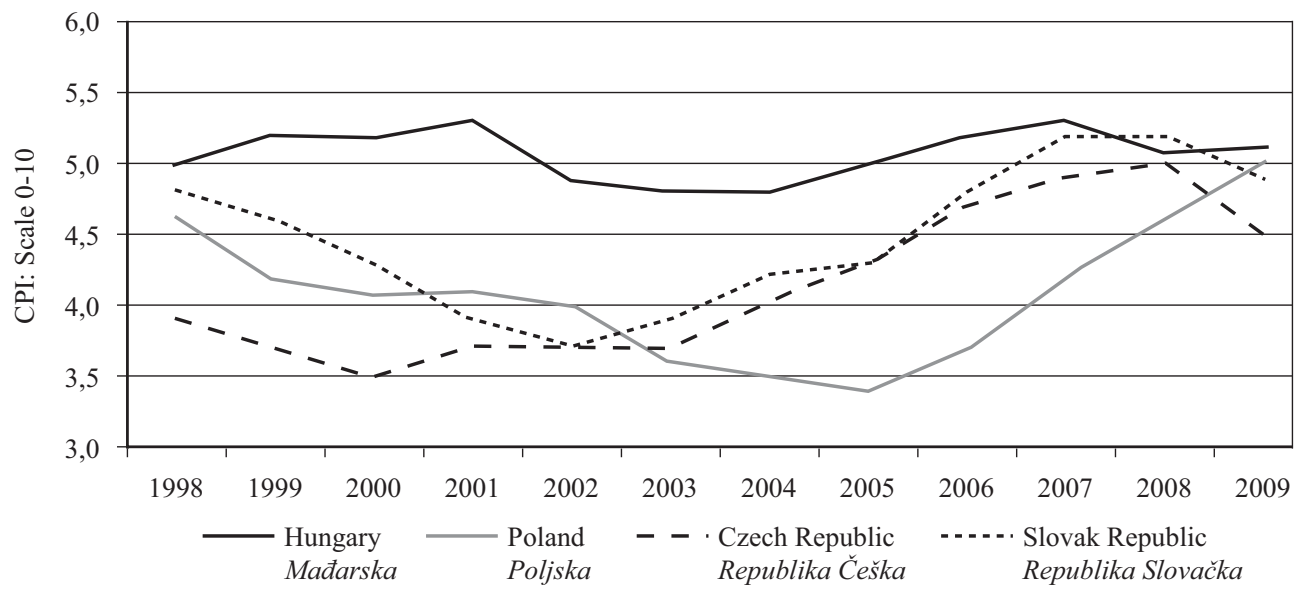

Figure 2 Corruption Perceptions Index in V4 countries in the period 1998-2009 (Scale: 0-10, 10 being the best, Source: Transparency International data)

Slika 2. Indeks percepcije koruptivnosti u zemljama V4 za razdoblje 1998 - 2009. (Skala: 0-10; 10 je najbolje; izvor: podaci Transparency Internationala)

Table 10 Corruption Perceptions Index in V4 countries in the period 1998-2009

Tablica 10. Indeks percepcije koruptivnosti u zemljama V4 za razdoblje 1998 - 2009.

\begin{tabular}{|l|c|c|c|c|c|c|c|c|c|c|c|c|}
\hline Country / Država & 1998 & 1999 & 2000 & 2001 & 2002 & 2003 & 2004 & 2005 & 2006 & 2007 & 2008 & 2009 \\
\hline Hungary & 5.0 & 5.2 & 5.2 & 5.3 & 4.9 & 4.8 & 4.8 & 5.0 & 5.2 & 5.3 & 5.1 & 5.1 \\
\hline Poland & 4.6 & 4.2 & 4.1 & 4.1 & 4.0 & 3.6 & 3.5 & 3.4 & 3.7 & 4.2 & 4.6 & 5.0 \\
\hline Czech Republic & 4.8 & 4.6 & 4.3 & 3.9 & 3.7 & 3.9 & 4.2 & 4.3 & 4.8 & 5.2 & 5.2 & 4.9 \\
\hline Slovak Republic & 3.9 & 3.7 & 3.5 & 3.7 & 3.7 & 3.7 & 4.0 & 4.3 & 4.7 & 4.9 & 5.0 & 4.5 \\
\hline
\end{tabular}

Drábek, 2011). In connection with the FDI inflow and encouragement of foreign companies to invest, it is necessary to present the investment incentives - all the measurable economic benefits provided by the host government to foreign investors for the purpose of motivation in business activities. The primary role of the investment incentives should be to motivate the investors to place their new projects in the so called disadvantages areas, which means in the regions with higher unemployment, lower infrastructure quality, etc. The positive impact of a new investment shall be proved by job creation, by chances for the graduates to be used as well as by creation of new entrepreneurial opportunities for local companies (Ministry of Economy, 2010).

Investment aid is a form of state aid targeted at promoting economic development of the most disadvantaged regions and at mitigating regional disparities. Granting of investment should stimulate the creation of new jobs.

Investment aid beneficiary can be a legal person or a natural person-entrepreneur with a registered office in the Slovak Republic, incorporated in the Commercial Register or the Trade License Register, ready to implement an investment plan in the Slovak Republic; the beneficiary must be $100 \%$ owned by the applicant, or the applicant must be a controlling person of the beneficiary. The beneficiaries' investment activities and projects have to be in compliance with the Act 565/2007 Coll. the "Act on Investment Aid".

One of the factors affecting the investor's decision on its investment placement is also the amount and the structure of the investment incentives that may be obtained. The so-called intensity of the aid means the maxi- mum proportion of the eligible costs that may be approved for the investor in the form of particular investment incentives. The maximum intensity differs depending on the district. The limit in Bratislava region is $0 \%$, Western Slovakia 20-40 \%, Central Slovakia 25-50 \% and Eastern Slovakia 25-50 \% (Ministry of Economy, 2010).

The Act on Investment Aid 565/2007 Coll. divides the projects that may be supported into four categories:

- Industrial production

- Technological centers

- Shared services centers

- Tourism

The main factors affecting the acquisition of investment aid are (Ministry of Foreign Affairs, 2009):

- Amount of investment

- Region in which the project will be implemented

- Unemployment rate in the region

- Number of direct and indirect jobs created

- Intensity of state aid in the region

- Technological standard, innovation

- Amount of training costs

- Share of highly qualified staff

- Environmental impact

- Quality of the investment plan and application completeness.

If the investor meets all the requirements of the investment aid in individual areas, it can apply for the following forms of investment incentives (Slovak Investment and Trade Development Agency, SARIO):

a) subsidy for the acquisition of material assets and immaterial assets,

b) an income tax relief, 
........ Merková, Drábek, Jelačić: Determinants of Effects of Foreign Direct Investment...

Table 11 Forms of investment incentives

Tablica 11. Oblici poticaja investicijama

\begin{tabular}{|c|c|}
\hline \multicolumn{2}{|l|}{$\begin{array}{l}\text { Forms of investment incentives in the Slovak Republic } \\
\text { Oblici poticaja investicijama u Slovačkoj Republici }\end{array}$} \\
\hline $\begin{array}{l}\text { Direct support for: } \\
\text { Izravna potpora za: }\end{array}$ & $\begin{array}{l}\text { Indirect support for: } \\
\text { Neizravna potpora } z a \text { : }\end{array}$ \\
\hline $\begin{array}{l}\text { construction / izgradnju } \\
\text { technology / tehnologije } \\
\text { research and development / istraživanje i razvoj } \\
\text { job creation, retraining of the workforce / nova radna mjesta, } \\
\text { izobrazbu kadrova } \\
\text { allowance for staff training / pozajmice za obuku kadrova } \\
\text { land acquisition and implementation of infrastructure / kupnju } \\
\text { zemljišta i uvođenje infrastrukture } \\
\text { loan policy, lower interest, longer repayment period, the state } \\
\text { guarantee / zajmove s nižom kamatom, duljim rokovima povrata, } \\
\text { državna jamstva }\end{array}$ & $\begin{array}{l}\text { income tax relief / oslobađanje od poreza na } \\
\text { dohodak } \\
\text { transfer of real estate or exchange of real estate for } \\
\text { the price lower than the general value / prijenos } \\
\text { nekretnina ili za iznajmljivanje nekretnina za manji } \\
\text { iznos od uobičajenoga } \\
\text { providing advisory services free of charge or for a } \\
\text { partial payment or deferred tax payment / davanje } \\
\text { savjetodavnih usluga bez naknade, za djelomično } \\
\text { plaćanje ili za plaćanje pojedinih poreznih davanja }\end{array}$ \\
\hline
\end{tabular}

Source: data of the Ministry of Economy in SR / Izvor: podaci Ministarstva gospodarstva Slovačke

Table 12 Overview of investment aid in Slovakia in the period 2002-2010 (mill. EUR)

Tablica 12. Pregled potpora investicijama u Slovačkoj u razdoblju 2002 - 2010. (mil. EUR)

\begin{tabular}{|l|c|c|}
\hline $\begin{array}{l}\text { Forms of investment aid in Slovakia in the period 2002-2010 } \\
\text { Oblici potpore investicijama u Slovačkoj u razdoblju 2002 - 2010. }\end{array}$ & $\begin{array}{c}\text { Approved } \\
\text { Odobreno }\end{array}$ & $\begin{array}{c}\text { Used } \\
\text { Iskorišteno }\end{array}$ \\
\hline $\begin{array}{l}\text { Subsidy for the acquisition of longterm assets / } \\
\text { Potpora za stjecanje dugotrajne imovine }\end{array}$ & 547.50 & 393.60 \\
\hline Contribution for new job creation / Potpora za kreiranje novih radnih mjesta & 92.70 & 48.11 \\
\hline Contribution for staff retraining / Potpora za obuku kadrova & 52.51 & 42.68 \\
\hline Income tax relief /Oslobođenje od poreza na dohodak & 439.39 & 90.06 \\
\hline Transfer or exchange of real estate / Prijenos ili promjena nekretnina & 46.69 & 46.69 \\
\hline Overall / Ukupno & 1178.79 & 621.16 \\
\hline
\end{tabular}

Source: data of the Ministry of Economy in SR / Izvor: podaci Ministarstva gospodarstva Slovačke

c) contribution for new jobs created,

d) transfer of immovable property or exchange of immovable property at a price lower than a general asset value.

Investment incentives mean the price or cost that the country must cover to some extent in connection with the inflow of foreign capital (in periods of deficit in domestic financial resources) considering the positive effects that FDI will bring (in the past it was the solution of two serious problems in the SR - employment growth, improved trade balance) (Drábek and Merková, 2010).

\subsection{Foreign direct investment flows in the SR and WPI SR}

3.3. Izravna strana ulaganja u Slovačku i u slovačku preradu drva

Data of the United Nation Conference for Trade and Development (UNCTAD) held in 2008 show that Slovakia was most highly ranked among $27 \mathrm{EU}$ countries according to the indicator of FDI inflows per capita $-16^{\text {th }}$ place with the value of $632 \mathrm{USD} /$ capita. The evaluation of the total FDI inflows in millions of USD, as well as the percentage of FDI in GDP of the country (17 $7^{\text {th }}$ place) show similar results.

At the beginning of transformation, Slovakia had similar comparative advantages as other countries in Central and Eastern Europe, particularly qualified and cheap labor, cheap raw material and energy inputs, good location and close relations with the EU. Until
2000, FDI inflows had risen, but its volume lagged behind the volume of FDI inflows in the other V4 countries (The concept of management of FDI, Ministry of Economy, 2009).

FDI inflows into the wood-processing industry (WPI) in the presented period of 5 years reached the largest volume in 2005 , amounting to 1.557 billion SKK, and however $90 \%$ of these resources was absorbed by the furniture industry. In other years, less than half of this value was achieved. The second largest inflow was in 2006, when 835 million SKK were invested into WPI. Pulp and paper industry dominated in 2006 and 2007 with the inflows of 608 million SKK and 606 million SKK of FDI, respectively.

The smallest amount of foreign investment flowed into the sector of wood industry (annually and totally) with the exception of 2004, when the wood industry recorded FDI inflows of 556 million EUR. The opposite trend was recorded in the industrial production of the Slovak Republic, with the lowest FDI inflows, amounting to 10.901 billion EUR, in 2005.

Stagnation of investment in sawmilling, construction and carpentry was reported in the period 1999-2002, and in the period 2003-2006 an increase was recorded amounting to nearly 1.7 to 2.6 billion Slovak crowns (SKK) per year (NLC, 2009). A significant increase of investment to the level of 6.07 billion SKK occurred in 2007, but this growth was followed by a drop to the level of 2.25 billion SKK. 


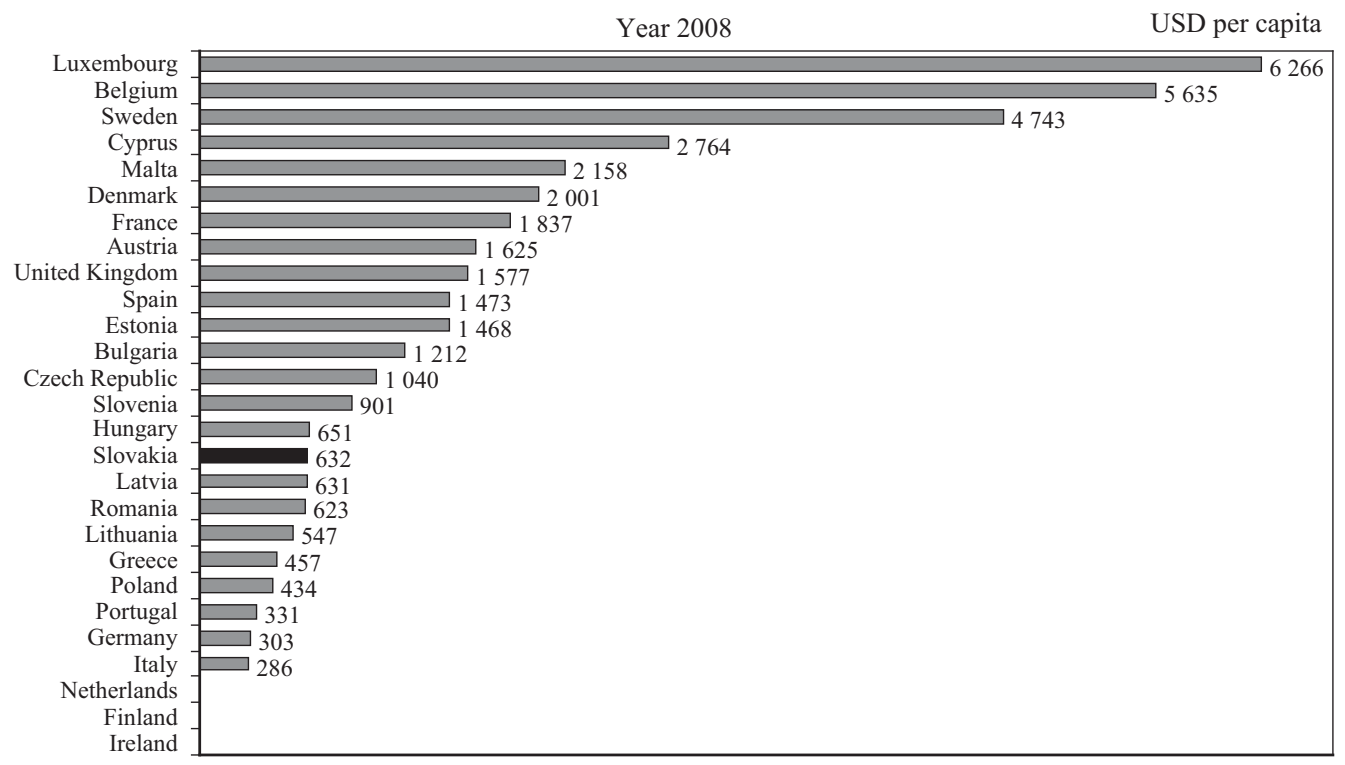

Figure 3 Foreign direct investment inflows per capita in the EU countries, USD per capita. (Source: Eurostat data, http://epp. eurostat.ec.europa.eu).

Slika 3. Izravna strana ulaganja po stanovniku zemalja EU, USD po stanovniku. (Izvor: podaci Eurostata, http://epp.eurostat. ec.europa.eu).

Table 13 Investment in the WPI and industrial production of the Slovak Republic (mill. SKK)

Tablica 13. Investicije u WPI i industrijsku proizvodnju Slovačke Republike (u mil. SKK)

\begin{tabular}{|c|c|c|c|c|c|c|c|c|c|c|c|}
\hline $\begin{array}{l}\text { Indicator } \\
\text { Pokazatelj }\end{array}$ & Sector / Sektor & 1999 & 2000 & 2001 & 2002 & 2003 & 2004 & 2005 & 2006 & 2007 & 2008 \\
\hline \multirow{5}{*}{$\begin{array}{l}\text { Investment } \\
\text { (millions } \\
\text { SKK) / } \\
\text { Investicije } \\
\text { (u mil. } \\
\text { SKK) }\end{array}$} & $\begin{array}{l}\text { Wood Industry (WI) / } \\
\text { Prerada drva (WI) }\end{array}$ & 506 & 881 & 766 & 734 & 1788 & 1710 & 2564 & 2573 & 6068 & 2249 \\
\hline & $\begin{array}{l}\text { Furniture Industry }(\mathrm{FI}) / \\
\text { Proizvodnja namještaja } \\
\text { (FI) }\end{array}$ & 580 & 1572 & 1645 & 701 & 794 & 1687 & 2024 & 2787 & 4512 & 1644 \\
\hline & $\begin{array}{l}\text { Pulp and paper Industry } \\
\text { (PPI) / Proizvodnja } \\
\text { pulpe i papira (PPI) } \\
\end{array}$ & 4785 & 1594 & 2205 & 3083 & 6634 & 5161 & 4744 & 3185 & 2796 & 3300 \\
\hline & $\begin{array}{l}\text { Wood Processing Indu- } \\
\text { stry (WPI) / Drvoprera- } \\
\text { divačka industrija (WPI) }\end{array}$ & 5871 & 4048 & 4616 & 4519 & 9216 & 8558 & 9331 & 8545 & 13375 & 7194 \\
\hline & $\begin{array}{l}\text { Industrial production / } \\
\text { Industrijska proizvodnja }\end{array}$ & 44489 & 42328 & 71077 & 56466 & 59152 & 71897 & 104046 & 105101 & 102993 & 98627 \\
\hline
\end{tabular}

Source: data from Ministry of Economy SR and Statistical Office of SR

Izvor: podaci Ministarstva gospodarstva Slovačke i Statističkog ureda Slovačke

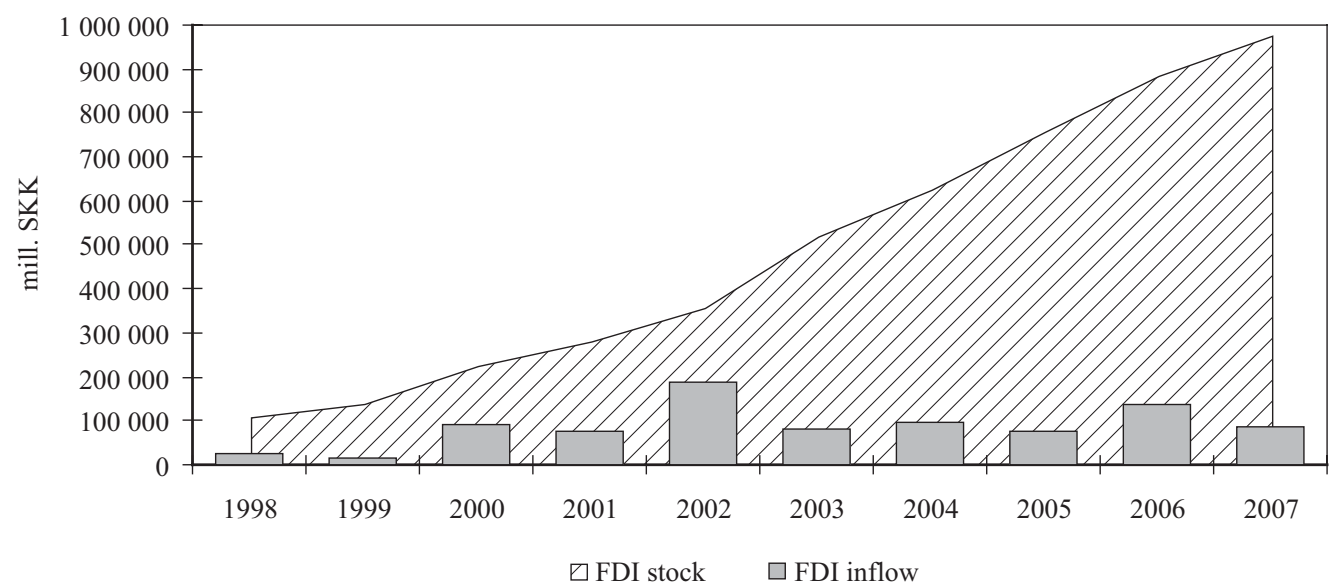

Figure 4 Foreign direct investments in the Slovak Republic, mill. SKK. (Source: NBS data, National Bank of Slovakia.) Slika 4. Izravna strana ulaganja u Slovačku, u mil. SKK. (Izvor: podaci NBS-a, National Bank of Slovakia.) 


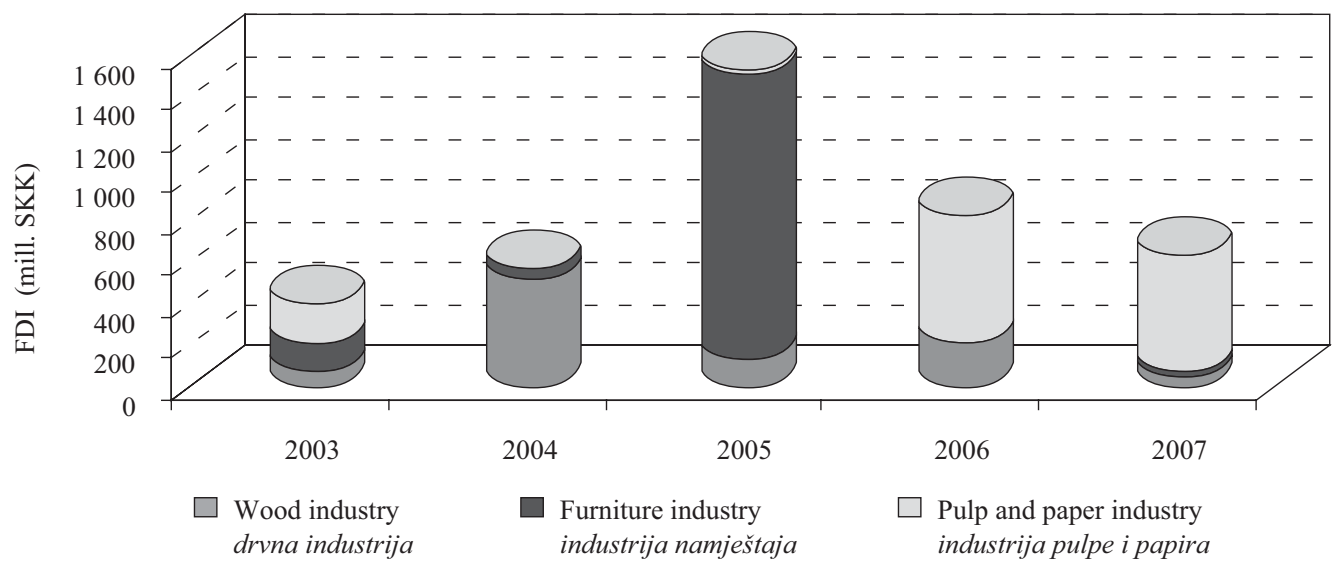

Figure 5 Inflow of FDI in sectors of wood-processing industry (mill. SKK)

Source: NBS data

Slika 5. FDI u sektor drvoprerađivačke industrije (u mil. SKK)

Izvor: podaci NBS-a

The sector of furniture production has seen better investment in the years 2000, 2001, 2004-2006 and this fact caused the growth of labor productivity. The investment was in the range of 1.5 to 2.8 billion SKK in the years mentioned above. Similarly as in the sector of wood industry (WI), in furniture industry (FI) an equally sharp increase was recorded in 2006-2008, from 2.8 billion SKK to 4.5 billion SKK in 2007 and then a fall to 1.6 billion SKK in 2008 .

Rapid changes of investment in the pulp and paper industry (PPI) were reported following the realization of significant business actions during the whole period. Major modernizations in this sector were made in 1999 and 2003-2005, but the overall trends suggest that the highest volume of investment of all three sectors of wood processing industry were made into the pulp and paper sector ranging between 1.6 and 6.6 billion SKK per year (Merková et al, 2011).

\subsection{Effects of investment and FDI in the SR and WPI SR}

3.4. Učinci investicija i FDI-a u Slovačku i slovačku preradu drva

Effects of investment and FDI were analyzed through correlation and regression analysis, which was applied to detect dependencies between investment and other economic indicators. Selected analytical results, which demonstrate the positive impact, are presented in Table 15.

The first significant dependence is between foreign direct investment stock in the SR and GDP growth of SR with the correlation coefficient $r=0.94$, which demonstrates that the growth of FDI causes GDP growth. Regression coefficient $b=0.000009$ means that the growth of FDI in 100 billion SKK causes the GDP growth of $0.9 \%$ on average.

Subsequent correlation and regression analysis examined the correlation between variables in the wo-

Bodový graf: Stav PZI v SR (mil. Sk) vs. Rast HDP SR (\%) (Celé př́íp. vynech. u ChD) Rast HDP SR $(\%)=, 32677+, 90 \mathrm{E}-5 *$ Stav PZI v SR (mil. Sk)

Korelace : $r=, 94339$

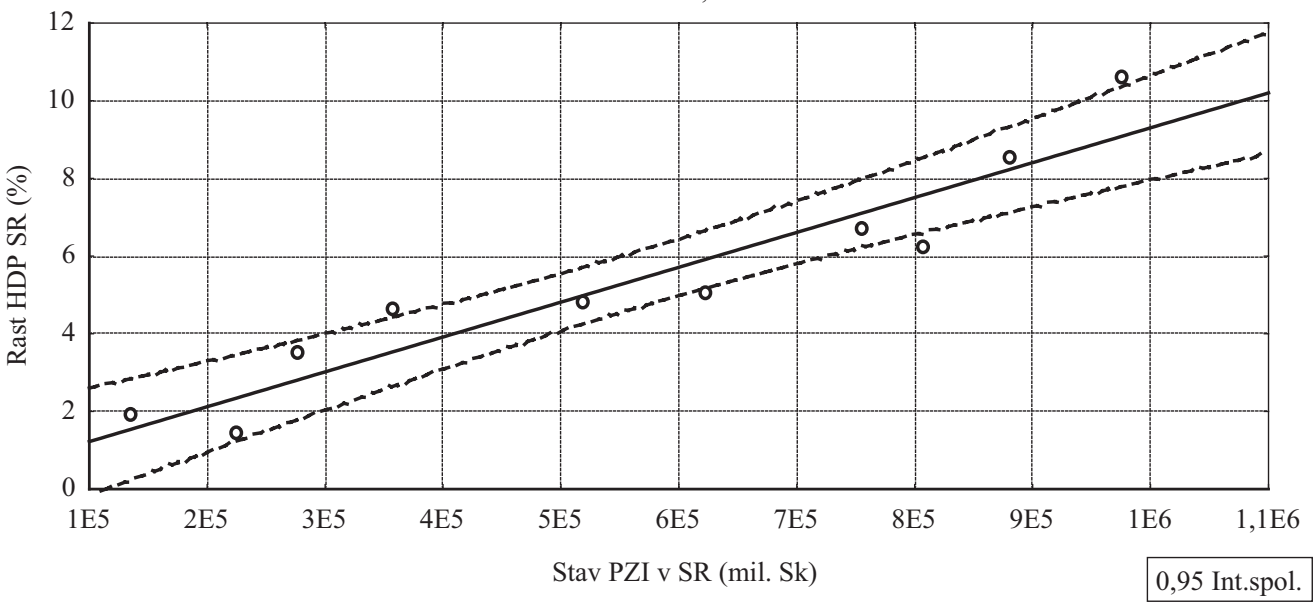

Figure 6 Correlation: FDI stock in SR GDP growth in SR (period 1999-2008)

Slika 6. Korelacija zaliha FDI-a u Slovačkoj i rast BDP-a u Slovačkoj (za razdoblje 1999 - 2008) 
Table 14 Selected results of correlation and regression analysis

Tablica 14. Odabrani rezultati korelacijske i regresijske analize

\begin{tabular}{|c|c|c|c|c|c|c|c|c|c|}
\hline $\begin{array}{l}\text { Va- } \\
\text { ria- } \\
\text { bles } \\
\text { Vari- } \\
\text { jabla }\end{array}$ & Indicator / Pokazatelj & $\begin{array}{l}\text { Unit } \\
\text { Mjerna } \\
\text { veličina }\end{array}$ & $\begin{array}{l}\text { Mean } \\
\text { Srednja } \\
\text { vrijed- } \\
\text { nost }\end{array}$ & $\begin{array}{c}\text { Standard } \\
\text { Deviation } \\
\text { stan- } \\
\text { dardna } \\
\text { devijacija }\end{array}$ & $\begin{array}{c}\text { Correla- } \\
\text { tion } \\
\mathrm{r} \\
\text { Korelaci- } \\
j a \\
r \\
\end{array}$ & $\begin{array}{l}\text { Determi- } \\
\text { nation } \\
\mathrm{r}^{2} \\
\text { Determi- } \\
\text { nacija } r^{2}\end{array}$ & $\begin{array}{c}\begin{array}{c}\text { Probabili- } \\
\text { ty of error } \\
\mathrm{p}\end{array} \\
\text { Vjerojat- } \\
\text { nost pogre- } \\
\text { ške p }\end{array}$ & $\begin{array}{c}\text { Constant } \\
\mathbf{a} \\
\text { Konstanta } \\
a\end{array}$ & $\begin{array}{l}\text { Slope } \\
\text { b) } \\
\text { Nagib } \\
\text { b }\end{array}$ \\
\hline$X$ & $\begin{array}{l}\text { FDI stock in SR } \\
\text { FDI zaliha u Slovačkoj }\end{array}$ & mill. SKK & 556169 & 297078 & & & & & \\
\hline$Y$ & $\begin{array}{l}\text { GDP growth in SR } \\
\text { rast BDP-a u Slovačkoj }\end{array}$ & $\%$ & 5,32 & 2,83 & 0,943394 & 0,889993 & 0,000042 & 0,326772 & 0,000009 \\
\hline$X$ & $\begin{array}{l}\text { Investment in WPI } \\
\text { investicije } u \text { WPI- } u\end{array}$ & mill. SKK & 7527 & 2885 & & & & & \\
\hline$Y$ & $\begin{array}{l}\text { GDP growth in SR } \\
\text { rast BDP-a u Slovačkoj }\end{array}$ & $\%$ & 5,32 & 2,83 & 0,842908 & 0,710494 & 0,002194 & $-0,90$ & 0,000826 \\
\hline$X$ & $\begin{array}{l}\text { Sales in WPI } \\
\text { prodaja } u \text { WPI- } u\end{array}$ & mill. SKK & 70017 & 19024 & & & & & \\
\hline$Y$ & $\begin{array}{l}\text { GDP growth in SR } \\
\text { rast BDP-a u Slovačkoj }\end{array}$ & $\%$ & 5,32 & 2,83 & 0,944034 & 0,891201 & 0,000040 & $-4,50275$ & 0,00014 \\
\hline$X$ & $\begin{array}{l}\text { Value added in WPI } \\
\text { dodana vrijednost } u \\
\text { WPI- } u\end{array}$ & mill. SKK & 15715 & 2587 & & & & & \\
\hline$Y$ & $\begin{array}{l}\text { GDP growth in SR } \\
\text { rast BDP-a u Slovačkoj }\end{array}$ & $\%$ & 5,32 & 2,83 & 0,779587 & 0,607756 & 0,007838 & $-8,06785$ & 0,00085 \\
\hline$X$ & $\begin{array}{l}\text { Investment in WPI } \\
\text { investicije } u \text { WPI }\end{array}$ & mill. SKK & 7527 & 2885 & & & & & \\
\hline$Y$ & $\begin{array}{l}\text { Sales in WPI } \\
\text { prodaja } u \text { WPI- } u\end{array}$ & mill. SKK & 70017 & 19024 & 0,792267 & 0,627687 & 0,006287 & 30687,77 & 5,224946 \\
\hline$X$ & $\begin{array}{l}\text { Investment in WPI } \\
\text { investicije } u \text { WPI }\end{array}$ & mill. SKK & 7527 & 2885 & & & & & \\
\hline$Y$ & $\begin{array}{l}\text { Labour productivity of } \\
\text { turnover in WPI } \\
\text { produktivnost rada } u \\
\text { obrtu WPI-a }\end{array}$ & $\begin{array}{l}\text { thousands } \\
\text { SKK }\end{array}$ & 2321 & 607 & 0,770233 & 0,593259 & 0,009143 & 1100,60 & 0,162090 \\
\hline
\end{tabular}

od-processing industry of SR, with the focus on the positive impact of investment and the value of fixed assets. Dependence of investment and sales in the WPI showed a correlation coefficient of $r=0.79$. Regression coefficient $b=5.22$ means that the growth in investment of 1 billion SKK causes sales growth amounting to 5.22 billion SKK. Dependence of in- vestment and labor productivity in WPI has a similar correlation coefficient $r=0.77$; the regression coefficient $b=0.162$ shows that growth in investment of 1 billion SKK causes labor productivity growth of 0.162 million SKK (Figure 10).

Development of the WPI indicators in 2008 and 2009 is due to the financial and economic crisis as well

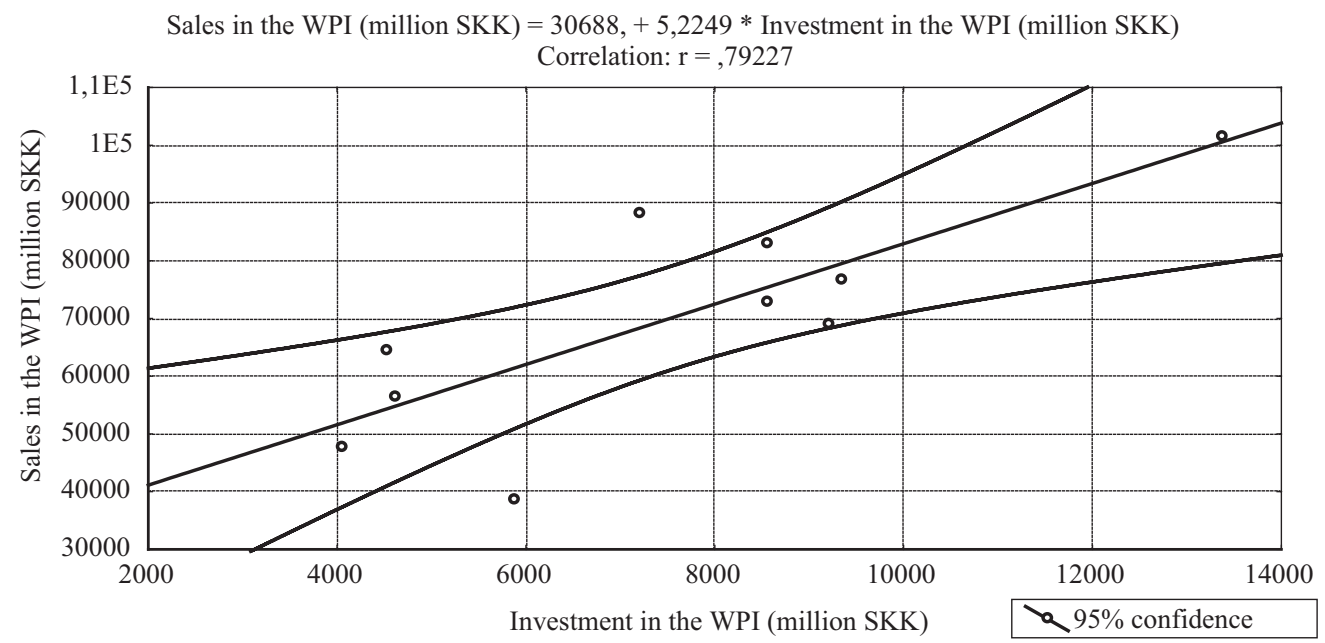

Figure 7 Correlation in the WPI: Investment $\sim$ Sales (period 1999-2008)

Slika 7. Korelacija za investicije i prodaju WPI-a (razdoblje 1999 - 2008) 
Productivity of sales in the WPI (thousand SKK) $=1100,6+, 16209 *$ Investment in the WPI (million SKK)

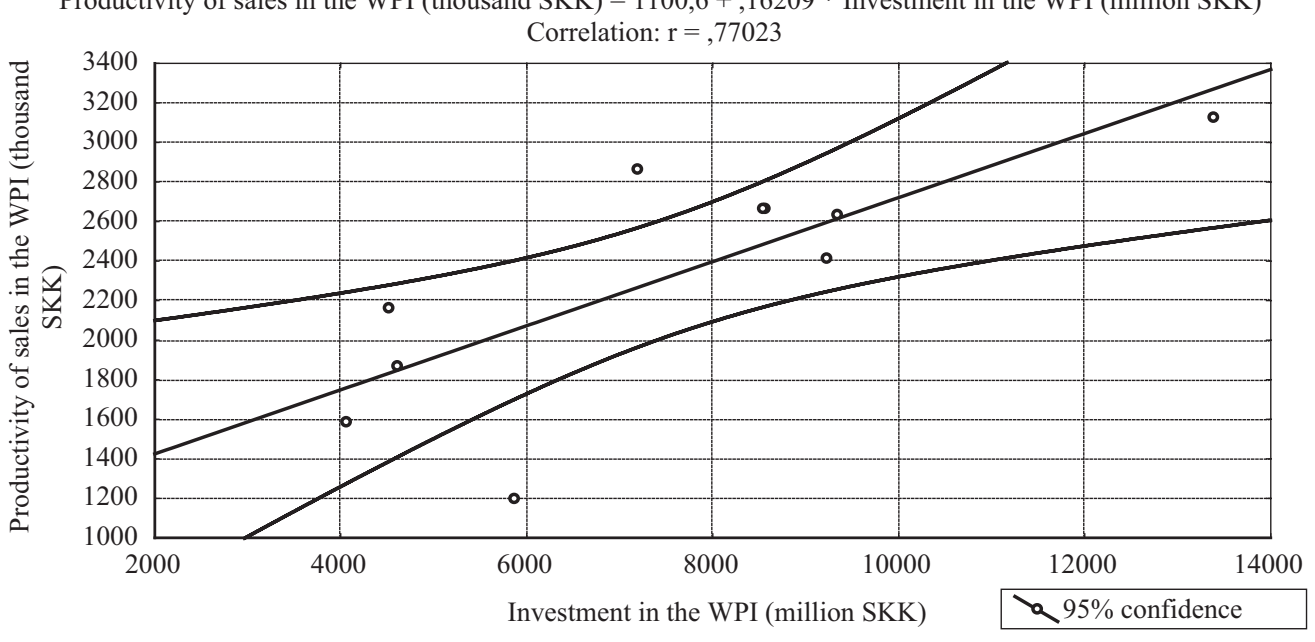

Figure 8 Correlation in the WPI: Investment $\sim$ Labor productivity (period 1999-2008)

Slika 8. Korelacija investicija i produktivnosti rada WPI-a (razdoblje 1999 - 2008)

as to the negative trend caused by unsolved problems for a long time, as shown by the annual decline in sales, value added and profit. Development of selected indicators is shown in Tables 15 to 17.

The employment dropped in all sectors of the WPI and it can be assumed that a smaller number of employees has an impact on labor productivity growth, resulting in wage increases, as correlation and regression analysis showed a high dependence (correlation coefficient 0.95 ) between labor productivity growth and wage growth.

\section{CONCLUSION \\ 4. ZAKLJUČAK}

The global financial crisis also had a negative impact on the development of the foreign direct investment flows. Since the end of 2008, global FDI inflows have decreased in all three forms. Equity shares, reinvested earnings and other capital flows (especially inside-corporate loans) fell mainly in developed economies. Investments in equity shares have been reduced due to the weakening of foreign mergers and acquisitions. Lower profits of subsidiary units contributed

Table 15 Selected indicators of wood industry

Tablica 15. Odabrani pokazatelji za preradu drva

\begin{tabular}{|l|c|c|}
\hline Indicator / Pokazatelj & 2008 & 2009 \\
\hline Total revenues (mil €) / ukupni prihod $($ u mil $€$ ) & 569 & 410 \\
\hline Value added (mil $€$ ) / dodana vrijednost $($ u mil $€$ ) & 104 & 75 \\
\hline After-tax profit (mil €) / dobit nakon oporezivanja $($ u mil $€$ ) & -2 & -41 \\
\hline Average number of employees / prosječni broj zaposlenih & 8590 & 6360 \\
\hline Average monthly wage $(€)$ / prosječna mjesečna plaća $(€)$ & 581 & 594 \\
\hline
\end{tabular}

Source: Trend analysis / Izvor: analiza trendova

Table 16 Selected indicators of furniture industry

Tablica 16. Odabrani pokazatelji za proizvodnju namještaja

\begin{tabular}{|l|c|c|}
\hline Indicator / Pokazatelj & 2008 & 2009 \\
\hline Total revenues (mil $€$ ) / ukupni prihod $(u$ mil $€$ ) & 706 & 573 \\
\hline Value added (mil €) / dodana vrijednost (u mil $€$ ) & 176 & 161 \\
\hline After-tax profit (mil €) / dobit nakon oporezivanja (u mil €) & 19 & 16 \\
\hline Average number of employees / prosječni broj zaposlenih & 11960 & 10470 \\
\hline Average monthly wage $(€)$ / prosječna mjesečna plaća $(€)$ & 650 & 641 \\
\hline
\end{tabular}

Source: Trend analysis / Izvor: Analiza trendova

Table 17 Selected indicators of pulp and paper industry

Tablica 17. Odabrani pokazatelji za proizvodnju pulpe i papira

\begin{tabular}{|l|c|c|}
\hline Indicator / Pokazatelj & 2008 & 2009 \\
\hline Total revenues (mil €) / ukupni prihod $(u$ mil $€$ ) & 1403 & 1227 \\
\hline Value added (mil €) / dodana vrijednost (u mil €) & 270 & 262 \\
\hline After-tax profit (mil €) / dobit nakon oporezivanja $($ u mil $€$ ) & 83 & 15 \\
\hline Average number of employees / prosječni broj zaposlenih & 7420 & 6790 \\
\hline Average monthly wage $(€)$ / prosječna mjesečna plaća $(€)$ & 904 & 959 \\
\hline
\end{tabular}

Source: Trend analysis / Izvor: analiza trendova 
to the decline in reinvested earnings (World Invesment Report, 2009). In the period of restructuring of parent companies, foreign subsidiary units were often involved in balancing the outstanding debt.

All economies have been affected by the global crisis in terms of decrease in exports and industrial production, the slowdown of FDI inflows and rising unemployment.

FDI inflows into the region of the V4 countries affect various factors in crisis. In relation to individual V4 countries, however, expectations are primarily the highest average GDP growth over the long term (Slovakia), a large domestic market (Poland) and a relatively stable service sector (Czech Republic, Hungary). The V4 countries in crisis and uncertain investors have the advantage of a predictable and well known environment, in the case of Slovakia even strengthened by the membership in the monetary union.

There is a review of the perception of prices, as investors will certainly not decide for the lowest current price - meaning low production costs and cheap labor or low tax cost - but primarily for the lowest cost throughout the life cycle of the investment (Jelačić et $a l, 2010)$. Apart from the quality of infrastructure, size of the domestic market or access to regional and international markets, foreign investors will particularly take into account the factors such as energy costs, availability of suppliers and customers, sufficient qualified and skilled workforce, predictability of economic development, stability of legislative conditions, security of companies and others. One of the biggest challenges of the Slovak economy is the ambition to remain an attractive country for foreign direct investment.

This paper is the result of a partial solution of the Ministry of Education grant project VEGA Nr. 1/0089/11 - Measurement and performance management of the wood industry companies in SR.

\section{REFERENCES}

5. LITERATURA

1. Drábek, J.; Jelačić, D., 2007. Investment projects. Zvolen, Vydavatel'stvo Nikara, 2007. 65s.

2. Drábek, J.; Merková, M., 2010. Efektívnost' priamych zahraničných investícií $\mathrm{v}$ odvetví spracovania dreva. Vydavatel'stvo TU Zvolen, pp. 103.

3. Drábek, J., Polach, J. 2008. Reálne a finančné investovanie firiem. Zvolen, Vydavatel'stvo TU vo Zvolene, 2008. 271s. ISBN 978-80-228-1934-3.

4. Ferenčíková, S., 2010. Stratégia medzinárodného podnikania: Investície, partneri a l’udské zdroje. Bratislava: Vydavatel'stvo EKONÓM, pp. 318.

5. Jelačić, D.; Bičanić, K.; Motik, D., 2010. Croatian wood processing and furniture manufacturing in a time of crisis. In Ekonomika a manažment podnikov 2010. CD ROM. Zvolen, p. 70-76.

6. Merková, M., 2010. Vplyv priamych zahraničných investícií na rozvoj odvetvia spracovania dreva. Školitel' Josef Drábek. Zvolen, Doktorandská dizertačná práca, DF TU Zvolen, pp. 135.

7. Merková, M.; Drábek, J., 2010. Effects and benefits of foreign direct investment for the development of wood- processing industry. In Wood processing and furniture manufacturing: present conditions, opportunities and new challenges. Vyhne: 2010. pp.125-133.

8. Merková, M.; Drábek, J., 2011: Potential of effects from foreign direct investment. In Development trends in economics and management in wood processing and furniture manufacturing. International Scientific Conference, Kozina, Slovenia, pp.115-124.

9. Merková, M.; Drábek, J.; Polách, J., 2011: Impact of Investment on Labour Productivity Growth in Wood Processing Industry in Slovak Republic. In Finance and the Performance of Firms in Science, Education and Practice. ISC. Tomas Bata University in Zlín, Zlín, pp. 324332.

10. Oblak, L.; Jelačić, D.; Motik, D.; Grladinović, T., 2008. A model for stock management in a wood-industry company. Wood research, 53 (1): 105-116.

11. Okali, I., et al. 2009. Hospodársky vývoj Slovenska v roku 2008. In Ekonomicky casopis, 2009, 57 (6): 524567.

12. Stasiak-Betlejewska, R.; Borkowski, S., 2007. The Role of a Foreign Capital in a Process of the Computerization of the Polish Bank Sector. In Ekonomika: problemi teorii ta praktiki. Zbirnik naukovich prac'. Vip. 231. T.IX. Dnipropetrovs'k: Wyd.DNU 2007, pp.1749-1759.

13. Koncepcia riadenia prílevu zahraničných investícií v kontexte globálnej finančnej a hospodárskej krízy. Vypracovalo MH SR v spolupráci s MZV SR. Uznesenie vlády SR č. UV-339/2009.

14. Odporúčania, ako zmiernit' následky globálnej krízy v lesnom hospodárstve, drevospracujúcom a celulózovo-papierenskom priemysle. Zvolen: NLC Zvolen, 2009.

15. Správa o stave podnikatel'ského prostredia v Slovenskej republike s návrhmi na jeho zlepšovanie. Predkladatel' MH SR. Uznesenie vlády SR č. UV-15097/2010.

16. World Investment Prospects Survey 2009-2011. New York, Geneva: UNCTAD, 2008. [online]. Dostupné na internete: http://www.unctad.org/en/docs/diaeia20098_en.pdf

17. World Investment Report 2009. Geneva: UNCTAD, 2009. [online]. Dostupné na internete: http://unctad.org/ en/docs/wir2009_en.pdf

18. Act. 565/2007 Coll. The Act of Investment Aid

19. http://epp.eurostat.ec.europa.eu [online].

20. http://www.economy.gov.sk [online].

21. http://www.foreign.gov.sk [online].

22. http://www.nbs.sk [online].

23. http://www.rokovania.sk [online].

24. http://www.sario.sk [online].

25. http://www.statistics.sk [online].

\section{Corressponding address:}

Ing. MARTINA MERKOVÁ, Ph.D.

Technical University in Zvolen

Faculty of Wood Sciences and Technology

Department of Enterprise Management

T. G. Masaryka 24

96053 Zvolen, SLOVAK REPUBLIC

E-mail: merkova@vsld.tuzvo.sk 